KAWISTARA

VOLUME $3 \quad$ No. 3, 22 Desember 2013

Halaman 227-334

\title{
SENI DOLALAK PURWOREJO JAWA TENGAH: PERAN PEREMPUAN DAN PENGARUH ISLAM DALAM SENI PERTUNJUKAN
}

\author{
Djarot Heru Santosa \\ Program Studi Seni Pertunjukan dan Seni Rupa Sekolah Pascasarjana \\ Universitas Gadjah Mada \\ Email:djarot_99@yahoo.com \\ Timbul Haryono \\ Fakultas Ilmu Budaya Universitas Gadjah Mada \\ R.M. Soedarsono \\ Institut Seni Indonesia Yogyakarta
}

\begin{abstract}
The role of women artists in the performing arts, also within the arts as well as the other broader life, in Indonesia, seems to be strengthening in recent years. It doesn't mean that it is a new issue, of course. But perhaps it happened since Indonesia experiencing and witnessing a great change of mainstream within it self since 1998; this issue, as well as the other critical issues gaining a more free momentum and space of expression. Of course, this still needs further scrutinization. The superiority of women is not limited to the mith in which giving special space for them, but indeed women have strong key role as the escort of performing arts. Women have the central key in promoting traditional arts; however, there is women role shift in the stage of performing arts. Women artists in the culture posseses inevitable duality of position. They are praised as high as the sky, in the other hand they are also insulted, abused, and used as a profit-making commodity. Besides their beautiful manner and behaviour, women are also capable of breaking through the boundary of culture. Women as the mother earth who's also identical with the symbol of fertility, paragon, and the parameter of values and norms that is expected by the social community, are also capable of fulfilling the promises attached into the miths that praise and adore them. Therefore, it is their nature that they have the central role in the success of a performing art both traditional and modern. Serious problems in the world of performing arts occur when women artists try to promote tradition. Inner conflict uccur between their basic nature and their environemntal condition. In this case, pressures are not only coming from the social environment but also from within. In fact, the soul of tradition survives and sustain from their very hands. When the stage experiences shift, the role of women as the escort of the tradition is also fading. Performance industry does properly place stage women as a subject but only as a commodity to attarct the market for the capitalists. Together, we should be able to solve this problem if we still want women to attend in the world of performing arts and change the world into a more colorful one.
\end{abstract}

Keywords: Dolalak Dance, Performig Arts, Women, and Community. 


\title{
SENI DOLALAK PURWOREJO JAWA TENGAH: PERAN PEREMPUAN DAN PENGARUH ISLAM DALAM SENI PERTUNJUKAN
}

\author{
Djarot Heru Santosa \\ Program Studi Seni Pertunjukan dan Seni Rupa Sekolah Pascasarjana \\ Universitas Gadjah Mada \\ Email:djarot_99@yahoo.com \\ Timbul Haryono \\ Fakultas Ilmu Budaya Universitas Gadjah Mada \\ R.M. Soedarsono \\ Institut Seni Indonesia Yogyakarta
}

\begin{abstract}
ABSTRAK
Peran seniman perempuan dalam seni pertunjukan, juga dalam wilayah kesenian serta kehidupan lain yang lebih luas di Indonesia, sepertinya memang sedang menguat tahun-tahun terakhir ini. Isu ini bukanlah sesuatu yang baru, tetapi barangkali sejak Indonesia mengalami dan menyaksikan arus perubahan besar yang terjadi di dalam dirinya sejak tahun 1998, isu ini, sebagaimana isu-isu kritis lain, mendapatkan momentum dan ruang ekspresi yang relatif lebih bebas. Hal ini tentu saja masih perlu pencermatan lebih lanjut. Kelebihan perempuan tidak hanya dalam batas mitos yang memberikan tempat khusus kepadanya, tetapi perempuan memiliki posisi penting sebagai pengawal seni pertunjukan yang tangguh. Perempuan memiliki peran sentral dalam mengangkat seni tradisi, kini ada pergeseran peran perempuan dalam panggung pertunjukan. Perempuan seniman dalam kebudayaan memiliki dualitas posisi yang tidak dapat dielakkan. Di satu sisi mereka dipuja setinggi langit, tetapi di sisi yang lain mereka juga dihina, dicaci, dan dijadikan sebagai komoditas pengeruk keuntungan. Di samping kecantikan budi serta perilaku, perempuan juga mampu menembus batas wilayah yang digariskan oleh budaya yang melingkupinya. Perempuan sebagai 'ibu bumi' yang identik dengan simbol kesuburan, suri teladan, dan tolok ukur nilai-nilai serta norma-norma yang diharapkan oleh komunitas sosial, perempuan mampu menunaikan janji yang terpatri dalam mitos-mitos yang menjunjung serta memujanya. Dengan demikian, sudah sewajarnyalah perempuan memiliki peran sentral dalam keberhasilan sebuah seni pertunjukan baik tradisional maupun modern. Persoalan serius yang menimpa para seniman perempuan dalam dunia seni pertunjukan adalah ketika mencoba mengangkat tradisi, terjadi pertentangan batin antara kodrat dengan tuntutan keadaan lingkungannya. Perempuan dalam hal ini tidak hanya ditekan dari masalah lingkungan sosial, tetapi juga tekanan yang berasal dari dalam dirinya. Padahal, kenyataannya adalah dari tangan-tangan merekalah, tradisi terus bertahan dan dihidupkan kembali ruhnya. Ketika dunia panggung mengalami pergeseran, peran perempuan sebagai penjaga tradisi dalam seni pertunjukan ikut memudar. Industri pertunjukan tidak lagi menempatkan para perempuan panggung sebagai sebuah subyek melainkan sekadar komoditas untuk menarik pasar bagi keuntungan pemodal. Masalah inilah yang harus bisa dipecahkan bersama jika tetap menginginkan perempuanperempuan hadir dalam jagat seni pertunjukan dalam rangka mengubah dunia menjadi lebih berwarna.
\end{abstract}

Kata Kunci: Tari Dolalak, Seni Pertunjukan, Perempuan, dan Masyarakat. 


\section{PENGANTAR}

Indonesia adalah negara yang memiliki letak dan posisi strategis sehingga sangat memungkinkan untuk menjadi jalur lalu lintas global berupa barang, ide, dan manusia. Keadaan seperti ini, tidak berpengaruh banyak bagi perkembangan seni pertunjukan. Seni pertunjukan umumnya dianggap statis dan dipandang mengakar di daerah atau pusat-pusat produksi tertentu, terpatri dalam ikatan-ikatan tidak tertembus genre dan berbagai tatanan patronase tradisional, dikungkung oleh laranganlarangan tradisional dan penghormatan terhadap leluhur (Cohen,2007:1). Soedarsono juga mengingatkan bahwa kegiatan seni, termasuk di dalamnya seni pertunjukan, meskipun selalu hadir dalam kehidupan manusia, tetapi di dalamnya memiliki sejumlah masalah dan perkembangan yang kompleks. Salah satu hal yang dicontohkan bahwa seni pertunjukan itu sebagai seni yang hilang dalam waktu, artinya apabila seni itu tidak dipentaskan, maka dapat hilang (Soedarsono, 2003:1).

Matthew Isaac Cohen berpendapat bahwa tradisionalisme semacam itu, setidaktidaknya untuk sebagian adalah warisan kesarjanaan Belanda yang cenderung melihat seni pertunjukan Indonesia dengan mengasumsikan kepastian dan ketaatan penuh pada aturan-aturan yang tidak dapat diganggu gugat. Para penulis seperti Jaap Kunst, Jacob Kats, dan Th. B. van Lelyveld menafsirkan musik, tari, serta teater Jawa dan Bali sebagai kesinambungan masa lalu. Penafsiran yang demikian mengakibatkan pendapat bahwa munculnya seni pertunjukan sebagai sebuah penyimpangan dan kemerosotan. Prasangka demikian akhirnya melembagakan wacana tentang pelestarian warisan budaya masa lalu dan strategi-strategi untuk mencegah kemungkinan kehilangan budaya.

Setiap negara memiliki warisan luhur budaya yang tidak ternilai dan menjadi kebanggan tersendiri baik bagi pemiliknya maupun semua pihak. Keadaan ini sudah sewajarnya memunculkan rasa yang mewajibkan semua pihak untuk melindungi dan menjaganya dari kerusakan dan kepunahan(Haryono, 2009:9-10). Kebudayaan Indonesia terdiri atas kebudayaan daerah yang beraneka ragam. Keanekaragaman itu tidak hanya menimbulkan perbedaan melainkan memperkaya dan memperkuat budaya bangsa. Salah satu dari tujuh wujud kebudayaan adalah kesenian. Menurut C. Geertz, seni pertunjukan dan bentukbentuk lain pergelaran budaya, termasuk seni pertunjukan tradisional, harus dilihat sebagai jendela-jendela istimewa untuk memahami pandangan dunia dan etos kelompok-kelompok etnis tertentu dengan nilai dan pemahaman, kebiasaan, dan norma tersendiri. Antroplog maupun peneliti lain didorong untuk "membaca [teks pertunjukan] menurut mereka yang berada di tempat semestinya" (Geertz, 1973:452), karena ekspresi budaya tidak lepas dari pernyataan bahwa keaslian sebuah budaya itu berwujud gagasan, pikiran, konsep, norma-norma, serta pandangan lokasi dalam kebudayaan yang bersangkutan.

Peristiwa-peristiwa dalam seni pertunjukan tradisional merupakan salah satu kegiatan ekspresi budaya masyarakat yang perlu diperhatikan dengan serius. Kesenian merupakan bagian dari kehidupan manusia. Setiap bangsa di dunia ini pasti mempunyai kekhasan dalam berkesenian. Bagi bangsa Indonesia, seni pertunjukan tradisonal merupakan salah satu bagian kehidupan masyarakat yang tidak dapat dipisahkan dengan sejarah dan perkembangan bangsa. Hampir seluruh kegiatan masyarakat ini selalu diikuti dengan peristiwa pertunjukan teater tradisional, misalnya seni pertunjukan difungsikan sebagai pengungkapan sejarah, keindahan alam, kesenangan, pendidikan, pengiring upacara ritual, hiburan, dan lain-lain (Bandem, 1996: 19). Peran dan keterlibatan unsur-unsur masyarakat dalam peristiwa seni pertunjukan adalah sangat luas, seluruh lapisan, dan unsur dalam masyarakat selalu ikut mendukung keberadaannya. Jadi, seni pertunjukan itu diciptakan, dilakonkan, dipertahankan, dan dikembangkan oleh masyarakatnya sendiri. 
Peran perempuan sebagai salah satu unsur yang ada dalam masyarakat, pada kegiatan seni pertunjukan sangat penting dan handal, kelebihan perempuan tidak hanya dalam batas mitos yang memberikan tempat khusus kepadanya, tetapi perempuan memiliki posisi penting sebagai pengawal seni pertunjukan yang tangguh. Di samping kecantikan budi serta perilaku, perempuan juga mampu menembus batas wilayah yang digariskan oleh budaya yang melingkupinya. Perempuan sebagai "ibu bumi" yang identik dengan simbol kesuburan, suri teladan, dan tolok ukur nilai-nilai serta norma-norma yang diharapkan oleh komunitas sosial, perempuan mampu menunaikan janji yang terpatri dalam mitos-mitos yang menjunjung serta memujanya. Dengan demikian, sudah sewajarnyalah perempuan memiliki peran sentral dalam keberhasilan sebuah seni pertunjukan baik tradisional maupun modern (Kusmiyati, 2006).

Salah satu bentuk penggunaan peran perempuan sebagai simbol identitas dalam seni pertunjukan tradisional adalah penaripenari perempuan dalam kesenian Dolalak di Kabupaten Purworejo. Totalitas mereka sebagai penyangga utama keberadaan seni Dolalak ternyata mendapat dukungan penuh dari masyarakat pemiliknya, bahkan tidak jarang mereka dianggap aset yang berharga dan bernilai tinggi bagi kelompok di komunitasnya. Hal inilah yang mungkin dapat menepis sementara anggapan bahwa peran mereka dalam berkesenian itu karena faktor eksploitasi saja. Sejalan dengan ini lebih lanjut Endang Caturwati berpendapat bahwa sejak dulu perempuan yang tampil dalam seni pertunjukan di manapun berada mengundang pro dan kontra. Penilaian masyarakat lebih banyak dikaitkan dengan perilaku negatif yang konotasinya mengarah pada eksploitasi, prostitusi, dan marjinal (Caturwati: 2003).

Kesenian Dolalak merupakan salah satu wujud kebudayaan bangsa yang muncul dan berkembang diwilayah Kabupaten Purworejo, Jawa Tengah. Awal munculnya seni pertunjukan Dolalak sejak masa kolonialisme
Belanda di Indonesia, sekitar tahun 1915. Kesenian ini juga merupakan sebuah adanya akulturasi budaya Barat (Belanda) dan Timur (Indonesia), hal ini dapat dilihat dari beberapa aksesoris dan busana yang dikenakan mirip dengan seragam serdadu atau tentara Belanda pada saat itu. Busana yang digunakan dalam tarian dolalak seperti baju lengan panjang dengan pangkat di bahu, celana pendek, topi, kaos kaki, dilengkapi dengan kaca mata hitam dan sampur adalah salah satu bukti perpaduan tersebut.

Tarian Dolalak memiliki berbagai gerak yang unik dan khas seperti kirig, ngetol, lilingan dan lain sebagainya, juga ada gerak dansa dan berbaris menirukan gerak-gerik serdadu Belanda. Di samping itu, disisipkan juga unsur magis yaitu dihadirkannya indang (roh halus) yang merasuk pada salah seorang penari, peristiwa ini biasa disebut trance atau mendem. Pada awalnya tarian ini ditarikan oleh penari pria, tetapi dalam perkembangannya sekarang lebih banyak ditarikan oleh penari perempuan serta biasanya tarian ini dipentaskan dalam durasi waktu yang cukup lama hinga sampai semalam suntuk. Adapun iringan tarinya menggunakan instrumen kendang, jidhur, terbang, dan vokal.

Kata Dolalak berasal dari lafal notasi nada do la la notasi lagu diatonis yang dinyanyikan oleh serdadu-serdadu Belanda dalam tangsi 'markas tentara'. Ucapan dominan yang dinyanyikan sambil menari-nari adalah do la la, yaitu dari lagu 1 - 6 - 6. Masyarakat Purworejo dan sekitarnya menirukannya menjadi dolalak, termasuk meniru gerakan dan motif busana yang dipakai serdadu Belanda. Pada perkembangan selanjutnya, Dolalak ini akhirnya menjadi kesenian rakyat Purworejo yang sangat populer. Asal-usul kesenian Dolalak ini ditemukan oleh tiga orang santri yang masih bersaudara yang menirukan gerak yang ditarikan serdadu Belanda. Mereka itu adalah Rejotaruno, Duliyat, dan Ronodimejo. Sekitar tahun 1925, ketiga santri itu bersama-sama masyarakat yang pernah menjadi serdadu Belanda membentuk kelompok kesenian Dolalak. 
Awalnya kesenian Dolalak tidak diiringi dengan instrumen musik dan cukup dengan vokal yang dinyanyikan secara bergantian oleh para penarinya. Perkembangan selanjutnya, masyarakat mulai menggemari kesenian tersebut, dan selanjutnya tarian dolalak diberi instrumen iringan dengan lagu-lagu tembang Jawa dan lagu Sholawatan. Pada dasawarsa ke-5 abad XX, kesenian dolalak ditarikan oleh kaum pria dan penyebarannya terbatas di wilayah tertentu saja. Akan tetapi, memasuki dasawarsa ke-7 abad XX pertunjukan Dolalak sudah boleh ditarikan oleh wanita, bahkan untuk selanjutnya, seni pertunjukan Dolalak lebih dikenal dengan perempuan semua sebagai penarinya.

Proses penyebaranya pun terhitung cepat karena dalam waktu singkat sudah meluas sampai seluruh wilayah Purworejo dan wilayah-wilayah sekitarnya, seperti Banyumas, Kebumen, Banjarnegara, dan Daerah Istimewa Yogyakarta. Di wilayah Purworeja, penyebarannya dimulai dari Desa Kaligoro kemudian merambah ke daerah Kaligesing dan akhirnya menyebar di seluruh wilayah Kecamatan Kaligesing. Berangkat dari Kecamatan Keligesing, kesenian Dolalak berkembang masuk sampai kota Purworejo dan menjadi tontonan/pertunjukan rakyat kota yang menarik dan sangat digemari oleh penduduk kota Purworejo. Semua lapisan masyarkat menilai bahwa pertunjukan tarian Dolalak merupakan pertunjukan rakyat yang sehat dan menghibur.

Dolalak sebagai sebuah seni pertunjukan merupakan sarana dan media untuk pengumpulan masa, sekaligus sebagai hiburan yang sehat, murah, dan meriah. Pada perkembangan selanjutnya iringan instrumen musiknya adalah beduk, terbang, kendang, kecer, kentongan, dan pianika/ organ. Tata busana penari memakai kaos kaki dan topi pet berikut slempang yang sudah dimodifikasi. Syair-syair lagu pengiringnya sudah mulai menggunakan bahasa Indonesia dan Jawa (tembang campursari) yang romantis. Properti khas penarinya adalah kaca mata hitam, terutama digunakan oleh penari wanita saat in trance/ kemasukan/ mendem. Untuk penampilan penari perempuan agar lebih segar dan cantik maka digunakan slendang, awalnya selendang ini hanya dililitkan pada pinggang, tetapi sekarang kebanyakan kelompok tari Dolalak sudah menggunakan sampur cendala giri yang diikatkan di depan seperti lazimnya orang menari Jawa sehingga juga bisa dimanfaatkan untuk alat sabet saat menari.

Seni pertunjukan Dolalak merupakan hiburan/tontonan yang meriah dan senantiasa menjadi kebanggaan masyarakat Purworejo dan sekitarnya, seluruh lapisan masyarakat baik kalangan pejabat, perangkat, kaya, miskin, agama, umur, pedagang, petani, remaja, pelajar, mahasiswa, lakilaki, wanita sangat menyukai tari Dolalak ini. Kepopuleran seni Dolalak ini tidak lepas dari peran sentral dari para penari-penari perempuannya, terutama penari perempuan yang dapat mengalami in trance.

Penelitian ini berbentuk kualitatif, maka dasar yang dipakai untuk analisisnya adalah data, kehadiran sumber data harus ditempatkan sebagai sebuah totalitas (Soedarsono, 1999:34 dan Alasuutari, 1996:812). Selanjutnya analisis kualitatif ini bersifat eksplanasi, yaitu menjelaskan sedetaildetailnya dari semua bagian informasi dari data dengan menggunakan kajian teoritis dari beberapa bidang keilmuan. Penggunaan teori ini diperlukan untuk menekan seminimal mungkin kontradiksi terhadap interpretasi data atau informasi yang disajikan.

Objek penelitian ini adalah sebuah peristiwa seni yang berupa seni pertunjukan, maka pendekatan utama yang dipakai untuk penelitian ini adalah performance studies 'studi atau ilmu tentang pertunjukan' Fokus dari pendekatan performance studies dalam penelitian ini pada unsur etnokoreologi karena salah satu objek kajian pada seni Dolalak adalah pada unsur utamanya, yaitu gerak tari. Etnokoreologi adalah kajian khusus mengenai unsur gerak tari, yang didukung oleh unsur musik, unsur syair lagu, dan unsur pendukung lainnya (Spradley, 1997:10). 
Tiga pendekatan di atas, yaitu etnografi, performance studies, dan etnokoreologi tidak dapat dilepaskan dari kajian aspek budaya lainnya. Kebudayaan didefinisikan oleh Geertz sebagai pola dari pengertianpengertian atau makna-makna yang terjalin secara menyeluruh dalam simbol-simbol dan ditransmisikan secara historis (Geertz, 1992: 1-2). Dikemukakan pula bahwa kebudayaan merupakan sistem mengenai konsepsikonsepsi yang diwariskan dalam bentuk simbolik, yang dengan cara ini manusia dapat berkomunikasi, melestarikan, dan mengembangkan pengetahuan dan sikapnya terhadap kehidupan.

Penelitian ini menggunakan metode kualitatif dengan penekanan pada prinsip kajian dari multidisiplin terhadap seni pertunjukan. Langkah awal penelitian ini, dimulai dari pengumpulan data tulis yang diperoleh dari sumber-sumber tertulis seperti naskah, manuskrip, partitur (naskah pertunjukan), artefak, buku, artikel, dan sebagainya. Data-data lisan dikumpulkan melalui wawancara dengan berbagai narasumber yang berhubungan dengan topik, rekaman audio, rekaman gambar/ photo, rekaman audio visual, dan observasi langsung (Soedarsono, 2001:128).

Pengumpulan data-data lisan dilaksanakan melalui penelitian lapangan dengan pengamatan dan pencatatan langsung terlibat (participant observation) secara sistematik (structured observation) di lingkungan komunitas seni pertunjukan Dolalak dan Angguk biasa dipentaskan. Waktu pelaksanaan kegiatan ini diperkirakan selama kurang lebih empat bulan dengan bantuan beberapa alat penelitian ini, di antaranya adalah rekaman gambar bergerak (video), foto, dan rekaman suara (tape recorder) untuk merekam data hasil observasi, wawancara, kamera, dan pedoman wawancara (interview guide).

Wawancara dilakukan secara semi terstruktur dengan pertanyaan-pertanyaan yang telah disiapkan dan bersifat terbuka untuk memberi kebebasan informan dalam mengemukakan pendapatnya. Wawancara mendalam (in-depth interview) juga digunakan apabila dibutuhkan data yang lebih bersifat spesifik (Endraswara, 2003). Data-data ini diperlukan untuk melihat sejarah dan persebaran seni pertunjukan angguk dan Dolalak.

Selanjutnya, data yang telah terkumpul dianalisis secara deskriptif yaitu fenomena budaya yang ditemukan diangkat, dijelaskan, dipahami, dan diuraikan secara logis dan berdasarkan konteks yang menyertainya. Interpretasi dan analisis data dilakukan dengan memilah-milah serta pengklasifikasian dari data yang terkumpul berdasarkan pada kategori-kategori tertentu, selanjutnya, data yang telah terkumpul dianalisis secara deskriptif yaitu fenomena budaya yang ditemukan diangkat, dijelaskan, dipahami, dan diuraikan secara logis dan berdasarkan konteks yang menyertainya, serta dikaitkan dengan teoriteori yang dipergunakan dalam penelitian ini untuk memecahkan masalah. Interpretasi digunakan untuk menghasilkan fakta yang terseleksi dalam rangka menyusun suatu kesimpulan dari kebenaran hasil kajian.

\section{PEMBAHASAN}

Purworejo dalam Persepektif Tradisi Lisan

Tradisi lisan merupakan tradisi yang berkembang di dalam masyarakat yang diceritakan dari mulut ke mulut dan secara turun temurun, dari satu generasi ke generasi berikutnya. Tradisi lisan erat kaitannya dengan adat istiadat yang melekat pada suatu masyarakat. Tradisi-tradisi lisan yang ada di suatu wilayah dapat berupa simbol, dongeng, legenda, adat istiadat atau kebiasaan, dan bentuk-bentuk yang lain. Kebanyakan dari tradisi lisan itu mengandung sebuah filosofi yang begitu diyakini oleh masyarakat sehingga menjadi seperti kepercayaan. Dari tradisi itu muncullah tujuan-tujuan yang melatarbelakangi adanya tradisi lisan tersebut.

Tradisi lisan tentang latar belakang sejarah wilayah Purworejo tidak dapat dilepaskan dari cerita rakyat tentang wilayah Bagelan. Informasi tentang wilayah Bagelen, 
pertama kali dikemukakan oleh A. Van Poel orang Belanda yang mengatakan bahwa nama Bagelen secara etimologi kata "Bagelen" berasal dari kata "pegel" yang artinya kesal karena untuk menyatakan rasa kesal yang berlebihan, maka kata tersebut menjadi "kepegelen", kemudian menjadi "pagelan", selanjutnya lebih mudah diucapkan dengan "bagelan". Van Poel mendapat informasi ini dari para kenthol Bagelen, yaitu priyayi atau bangsawan setempat yang ada di tanah Bagelen.

Cerita rakyat Bagelen berupa kisah tokoh Jaka Awu-Awu Langit dengan Roro Rengganis yang berasal dari Gunung Kelir. Menurut cerita, Roro Rengganis adalah seorang pengrajin tenun bersuami seorang petani bernama Jaka Awu-Awu Langit. Suatu hari kedua suami istri tersebut sedang sibuk dengan pekerjaannya masing-masing, tiba-tiba Sang istri Roro Rengganis merasa kehilangan anaknya dan melaporkannya kepada Sang Suami. Setelah mendapat laporan dari istrinya, Jaka Awu-Awu justru menyalahkan istrinya yang dianggap lalai karena tidak dapat menjaga anak dengan baik. Kemudian keduanya mencari dua anaknya yang hilang tersebut. Akhirnya, kedua anak mereka ditemukan ditumpukan jerami yang disusun ayahnya sewaktu bekerja. Ketika kedua suami istri ini mengetahui bahwa kedua anaknya telah meninggal, maka suami istri tersebut bertengkar hebat dan saling menyalahkan.

Jaka Awu-Awu kemudian pergi meninggalkan rumah bersama satu anak lainnya yang masih hidup. Sepeninggal suaminya, Roro Rengganis merasa duka yang mendalam hingga hatinya memiliki perasaaan pegel 'kesal'. Dari kata pegel itu konon dirangkai menjadi "kepegelan", lama-lama menjadi pagelan dan selanjutnya menjadi Bagelan. (Penadi, 2005:26). Berdasar cerita rakyat tersebut, tempat tinggal Roro Rengganis ini dikenal dengan nama wilayah Bagelen.

Sumber dari Tradisi lisan lainnya menyebutkan bahwa hamparan wilayah yang subur di Jawa Tengah bagian selatan antara Sungai Progo sampai dengan Cingcingguling sejak zaman dahulu kala merupakan kawasan yang dikenal sebagai wilayah yang masuk Kerajaan Galuh. Oleh karena itu, wilayah tersebut disebut sebagai wilayah Pagaluhan, jika diartikan dalam bahasa Jawa Pagalihan. Dari nama Pagalihan ini lama-lama berubah menjadi Pagelen dan terakhir menjadi nama Bagelen. Di kawasan tersebut mengalir sungai yang besar, yang waktu itu dikenal sebagai sungai Watukuro. Nama "Watukuro" sampai sekarang masih tersisa dan menjadi nama sebuah desa terletak di tepi sungai dekat muara sungai di Kecamatan Purwodadi, Kabupaten Purworejo. Di kawasan lembah Sungai Watukuro masyarakatnya hidup makmur dengan mata pencaharian pokok dalam bidang pertanian. (Wawancara Narasumber, 15 Mei 2010)

Keberadaan dan kebesaran wilayah Bagelen, juga dapat dihubungkan dengan penemuan peninggalan sejarah berupa prasasti dari masa Mataram Hindu. Wilayah Bagelen seperti yang digambarkan oleh W.J. Van Der Meulen SJ sebagai nama lain dari Holin atau Ho Ling (dalam kitab sejarah Dinasti Tang kuno \pm 618-906) merupakan sebuah kerajaan di Jawa, sebuah pulau di Laut Selatan. Kotanya dikelilingi pagar kayu, rajanya berdiam di istana bertingkat dan beratap daun palma. Penduduknya pandai menulis dan mengenal ilmu falak. Nama 'holing' merupakan perubahan nama dari Halin, singkatan dari Bhagahalin, sebuah kerajaan yang berlokasi di lembah Sungai Bogowonto. Sekitar tahun 600 Masehi, Ratu Sanjaya mendirikan sebuah kerajaan di Bagelen dengan wilayah berbentuk segitiga yang berpusat di Ledok bertempat dipojok paling utara dari wilayah Bagelen. Wilayahnya meliputi pantai selatan dengan puncak Gunung Prahu (Dieng) dan Bogowonto sebagai sungai utama. (Van Der Meulen, 1988:26).

Nama Bagelen juga sudah terkenal sejak masa sebelum masa kejayaan Kerajaan Mataram Islam. Peranan para Jawara atau Kenthol Bagelen dalam peperangan Kerajaan Mataram sangat besar. Pada masa pemerintahan Sultan Agung, dalam 
memadamkan pemberontakan Dipati Ukur, pasukan Bagelen turut berpartisipasi. Pada masa Kerajaan Matara Islam, wilayah Negara Agung dibagi menjadi delapan bagian, (Margono, 2010:1) sebagai berikut:

(1) Daerah Bumi (Kedu sebelah barat Sungai Praga) meliputi 6.000 cacah

(2) Bumi Jo (Kedu sebelah timur Sungai Progo) meliputi 6.000 cacah.

(3) Bumi Jo (Kedu sebelah timur Sungai Progo) meliputi 6.000 cacah.

(4) Siti Ageng Kiwo (sisi sebelah kiri jalan besar Pajang Demak) meliputi 10.000 cacah.

(5) Siti Ageng Tengen (sisi sebelah kanan jalan besar Pajang Demak) meliputi 10.000 cacah.

(6) Sewu (daerah Bagelen antara Sungai Bogowonto sampai Sungai Donan, Cilacap) meliputi 6.000 cacah.

(7) Numbak Anyar (daerah Bagelen antara Sungai Bogowonto sampai sungai Progo) meliputi 6.000 cacah.

Pola pembagian kewilayahan Mataram Islam yang menempatkan raja secara berurutan dikelilingi oleh Keraton, Negara, Negara Agung, dan Manca Negara. Keraton dan Negara adalah pusat kerajaan yang berfungsi sebagai ibukota seluruh negeri. Wilayah Bagelen pada masa pemerintahan Sultan Agung termasuk ke dalam wilayah Negara Agung (Negara Gedhe) yang masih ada di sekitar Kutagara. Negara Agung sendiri merupakan suatu wilayah di luar Negara yang berisi tanah mahosan dalem atau tanah yang diperuntukkan bagi pemasukan pajak ke kas keraton dan tanah jabatan para bangsawan keraton.

Pada tahun 1655, Sultan Amangkurat I mengangkat empat orang wedana pesisir. Bersamaaan dengan itu, Sultan juga mengangkat empat wedana jaba atau wedana luar atas Negara Agung, yaitu Surakarta, Yogyakarta, Kedu, dan Bagelen. Selain itu, pada peristiwa perang antara Mataram dan Banten, dalam rombongan ekspedisi militer ke Karawang, terdapat armada kapal yang tiga di antaranya diisi prajurit Bagelen. Masing-masing dipimpin oleh Kenthol
Abadsara (Ampatsara), Kenthol Pusparaga, dan Wangsamarta (Penadi, 2005:26).

Tanggal 28 Juni 1677, Keraton Plered jatuh ke tangan pemberontak Trunojoyo dan memaksa Sultan Amangkurat I keluar dari keraton. Hari Senin, 29 Juni 1677, rombongan kerajaan sampai di Jagabaya yang termasuk wilayah Bagelen dan bertemu dengan pasukan pemberontak. Beruntung, datang bala bantuan dari Kyai Baidowi bersama rakyat Bagelen. Sultan berhasil selamat dan mengeluarkan sebuah pantangan bagi anak keturunannya agar tidak menyeberangi Sungai Bogowonto membawa pasukan. Atas bantuan dari Kyai Baidowi dan rakyat Bagelen, Sultan bersama permaisuri membangun sebuah masjid yang dikenal sebagai Masjid Santren yang di dalamnya terdapat angka tahun 1679. Pembangunan Masjid Santren yang diarsiteki oleh Khasan Muhammad Shuufi tersebut menandai perkembangan agama Islam di wilayah Bagelen. Masjid Santren disebut sebagai masjid tertua di wilayah Bagelen (Imansyah Hadad, 2006:45).

Ketidakberhasilan VOC atau Vereenidge Oost Indische Compagni sebagai penengah dalam berbagai masalah di Mataram menimbulkan banyak pemberontakan. Selain itu, upaya VOC juga menimbulkan kerugian bagi Mataram. Setiap bantuan yang diberikan, pasti berujung pada penyerahan satu wilayah yang bernilai ekonomis bagi Mataram. Misalnya, daerah Kedu, Semarang, Pacitan, dan Grobogan yang menjadi milik VOC sebagai imbalan atas campur tangannya. Apalagi sejak peristiwa pembantaian orang Tionghoa di Jakarta tahun 1740, membuat arus perlawanan meluas ke berbagai daerah, termasuk Mataram. Pangeran Mangkubumi yang sebenarnya berhasil memadamkan perlawanan Mas Said, justru dikhianati sehingga berbalik bersekutu dengan Mas Said untuk melawan Sunan Pakubuwana II. Di Bagelen sendiri, perlawanan Mas Said mendapat dukungan yang luas (Kartodirdjo, 1988:229-230).

Akhirnya, pada 12 Februari 1755 dicapai sebuah kesepakatan tentang pembagian 
wilayah antara Sunan Pakubuwono III dan Pangeran Mangkubumi dengan perantaraan VOC. Peresmian perjanjian diadakan di desa Giyanti dan keesokan harinya Pangeran Mangkubumi diangkat menjadi Sultan Yogyakarta dengan gelar Hamengkubuwono. Masing-masing pihak mendapat wilayah seluas 53.100 cacah dan daerah Mancanegara dibagi dua, untuk Sunan seluas 33.350 cacah, dan Sultan seluas 33.950 cacah. Kerajaan Mataram akhirnya terbagi juga menjadi dua dan keputusan ini dianggap yang paling tepat karena masih memungkinkan terjadinya penyatuan kembali.

Untuk wilayah Bagelen sendiri dibagi antara kekuasaan Kasultanan Yogyakarta dan Kasunanan Surakarta dengan batas yang tidak jelas. Pembagian yang tumpang tindih serta ketidakjelasan dalam batas wilayah sering membawa pertikaian di kalangan penguasa lokal. Misalnya, terjadi perebutan tanah lungguh oleh para Gunung atau pembesar tanah yang ditugasi oleh keraton. Tirtonegoro, pimpinan para Gunung dari Kasunanan Surakarta yang berkedudukan di Cangkrep diganti dengan Ngabehi Resodiwiryo yang diangkat sebagai Lurah Gunung oleh Pangeran Kusumayuda atas nama Sunan. Tanah lungguh adalah tanah gaduhan raja yang diberikan kepada pangeran dan pejabat kerajaan yang diatur dengan jumlah cacah (petani penggarap). Tanah lungguh diatur dengan sistem pancasan yaitu satuan tanah lungguh para pejabat, tanahnya tidak terlalu luas dan letaknya tersebar. Pengaturan ini bertujuan agar pejabat di daerah hanya memiliki kekuatan terbatas sehingga tidak memungkinkan untuk memberontak. Tanah lungguh digunakan sebagai pengganti gaji karena sistem ekonomi uang belum dikenal luas (Laksono, 1985:76).

Sebagai wilayah Negara Agung pada masa Kerajaan Mataram, pembagian wilayah Bagelen pasca-Perjanjian Giyanti juga hampir sama sebagai berikut:

(1) Tanah Mahosan Dalem, yaitu tanah lungguh milik raja. Untuk Kesultanan Yogyakarta meliputi Bapangan (Jenar),
Semawung (Kutoarjo), Ngrawa, Watulembu, Lengis (Kedungkamal), Selomanik (Wonosobo), dan Semayu. Sedangkan untuk Kasunanan Surakarta meliputi Tanggung (Cangkrep), Wala (Ambal), Panjer (Kebumen), dan Tlaga.

(2) Tanah lungguh, yaitu tanah gaduhan raja untuk para pangeran dan pejabat kerajaan. Untuk Kasultanan Yogyakarta meliputi Loano, Blimbing(Karanganyar), dan Rama Jatinegoro (Karanganyar). Sedangkan untuk Kasunanan Surakarta meliputi Merden dan Kutowinangun.

(3) Daerah kerja Gladak, yaitu daerah yang penduduknya dikenakan wajib kerja di istana atau hutan. Untuk Kasultanan Yogyakarta terletak di Selomerto dan untuk Kasunanan Surakarta terdapat di Gesikan (Kutoarjo).

(4) Tanah bagi para pemuka atau lembaga keagamaan dan penjaga makam yang menjaga makamkeramat. Penentuannya bergantung pada kebijakan masingmasing penguasa lokal.

Informasi lain tentang sejarah wilayah Bagelen dan Purworejo pada masa lalu adalah ketika pasca-perang Diponegoro, Bagelen telah berubah menjadi sebuah kota yang terlahir kembali. Kotanya dibentuk lengkap dengan sistem sanitasi dan fasilitas transportasi sebagai sebuah unit pemukiman yang disesuaikan dengan sistem pertahanan maupun kepentingan ekonomi. Sistem tata kota yang demikian ini kemudian menjadi sebuah tatanan baru dalam pengembangan kota-kota di Indonesia pada masa kolonial. Semua itu dilakukan sebagai upaya antisipasi serta bentuk penjagaan terhadap kekuasaan Kasultanan Yogyakarta.

Demikianlah, Bagelen merupakan sebuah wilayah di pesisir selatan Jawa Tengah yang sekarang lebih dikenal sebagai Purworejo. Purworejo merupakan nama baru sebagai pengganti nama Brengkelan, ibukota Karesidenan Bagelen. Karesidenan Bagelen terdiri atas Kabupaten Brengkelan (Purworejo), Kabupaten Semawung (Kutoarjo), Kabupaten Karangduwur 
(Kemiri), dan Kabupaten Ngaran (masuk wilayah Kebumen). Kabupaten Purworejo sekarang meliputi wilayah yang termasuk ke dalam Karesidenan Bagelen dahulu, yaitu gabungan antara wilayah Brengkelan, Semawung, dan Karangduwur. Kedudukan Bagelen sebagai sebuah karesidenan kemudian dihapus pada 1 Agustus 1901 dan dimasukkan ke dalam wilayah Karesidenan Kedu. Sementara nama Bagelen sekarang hanya dipergunakan sebagai nama sebuah kecamatan di Kabupaten Purworejo (Imansyah Hadad, 2006:20).

\section{Sosok Perempuan Jawa dalam Seni Pertunjukan}

Nama seniman Waljinah adalah contoh sosok perempuan Jawa, demikian pula tokoh Srinthil dalam film Sang Penari. Tradisi Jawa memberikan konsepsi bahwa perempuan sejati adalah perempuan yang tetap tampak lembut, berperan dengan baik di rumah sebagai ibu maupun istri, berbakti dengan melebur di dapur maupun tempat tidur. Masyarakat Jawa berharap perempuannya bersikap dan berperilaku halus, rela menderita, dan setia. Kaum perempuan diharapkan dapat menerima segala sesuatu bahkan yang terpahit sekalipun.

Berkaitan dengan prinsip "hormat", sedapat mungkin perempuan Jawa tidak tampil dalam sektor publik karena secara normatif perempuan tidak boleh melebihi peran kaum laki-laki. Pada awalnya keluarga Waljinah sangat melarang Waljinah sebagai seorang penyanyi atau berkecimpung dalam dunia seni pertunjukan karena sebagai perempuan Jawa, pekerjaan sebagai penyanyi dianggap rendah. Akan tetapi, hal ini tidak berpengaruh dalam diri Waljinah. Jika dilihat dalam perspektif feminisme, Waljinah pada masa itu menyadari adanya ruang-ruang yang dapat dipilih perempuan untuk memilih profesi sebagai penghibur. Kenyataan selanjutnya, membuktikan orangorang di sekitar Waljinah akhirnya dapat menerima hal itu karena adanya legitimasilegitimasi peristiwa yang menyertainya, seperti kepopuleran nama, kemudahan mencari harta, kedudukan yang istimewa dalam lingkungannya, dan lain-lain.

Seiiring waktu, pandangan feodalistik yang cenderung memposisikan kaum perempuan di bawah subordinasi kaumlelaki semakin terkikis. Sudah bukan zamannya lagi seorang istri hanya hanya menunggu kepulangan sang suami sekadar ingin melolos sepatu atau dasi yang diyakini sebagai simbol kesetiaan. Memang harus diakui, pandangan feodalistik semacam itu tidak selamanya negatif. Setidaknya, nilai etika, kesetiaan, kelembutan, dan keharmonisan merupakan nilai positif yang terpancar dari sosok perempuan Jawa sebagaimana tergambar dalam Serat Centhini. Dalam konteks demikian, perempuan pasca-Jawa alias perempuan Jawa modern, seringkali dihadapkan pada situasi dilematis, antara mengikuti arus modernisasi dengan segenap dinamikanya; atau tetap menjadi sosok perempuan yang sarat sentuhan nilai tradisi; lembut, serba mengalah, sendika dhawuh, dan pasrah. Meminjam istilah Emile Durkheim, kaum perempuan "pasca-Jawa", sebuah istilah untuk menyebut situasi sedang berada dalam kondisi yang menyerupai anomie (keadaan di mana nilai-nilai, peraturanperaturan, dan kontrol sosial tidak lagi mengekang individu) (K.J.Veeger,1993;192). Hal ini sesuai dengan kondisi perempuan Jawa pada masa itu yang masih menaruh rasa hormat dengan tinggi terhadap budaya Jawa, tetapi gaya hidupnya sudah universal dan moderen.

Tampaknya, kaum perempuan pascaJawa memang harus mencermati secara serius terhadap kondisi anomie yang mau atau tidak harus dilaluinya. Pertanyaan yang muncul kemudian adalah bagaimana mewujudkan sosok perempuan pasca-Jawa yang tidak kehilangan identitasnya atau jatidiri "ke-Jawa-annya" di tengah-tengah kuatnya arus transformasi budaya yang kuat.

Mitos kanca wingking memang harus dibebaskan. Kaum perempuan dituntut untuk mampu tampil mandiri, dinamis, kreatif, penuh inisiatif, dan profesional dalam mengambil perannya di sektor 
publik, termasuk dalam dunia profesi seni. Meskipun demikian, bukan berarti harus meninggalkan "naluri" keibuan yang penuh sentuhan perhatian dan kasih sayang terhadap anak dan suami, lembut, hormat, etis, dan bermartabat tinggi.

Penampilan perempuan dalam seni pertunjukan hibitusnya (pengetahuannya) terbentuk dari pengalaman empiris yang diperoleh secara formal maupun non-formal dalam lingkungan sosialnya. Performatif perempuan dalam seni pertunjukan melalui tindakan tubuh sebagai hal yang lebih ditonjolkan sebagai alat untuk mempengaruhi (baca: menarik) orang yang menontonnya. Kekuatan bahasa tubuh pada diri perempuan telah menjadikan dirinya dipermudah jalan untuk mencapai tujuan dalam mempengaruhi orang lain, meminjam istilah-istilah sebelumnya adalah "mengubah dunia".

Performativitas perempuan di jagat seni pertunjukan tidak hanya dilakukan sematamata penampilan visual melainkan juga digunakan untuk melegitimasi kekuatan dan jati diri perempuan dalam lingkungan sosial. Kontribusi estetik untuk menunjukan identitas feminitas yang tetap digunakan untuk mempertahankan dan merefleksikan nilai-nilai kultural, sosial, dan keluarganya.

\section{Peran Perempuan dalam Pertunjukan Seni Dolalak}

Kesenian adalah salah satu di antara tujuh unsur kebudayaan yang bersifat universal. Pada umumnya kesenian yang tumbuh dan berkembang dalam masyarakat bersifat sosio religius. Maksudnya kesenian tidak dapat dipisahkan dengan kehidupan sosial, dan kesenian muncul untuk kepentingan yang erat hubungannya dengan kepercayaan masyarakat setempat (Sujono, dkk., 2003). Di dalam setiap pementasannya beberapa bentuk kesenian tradisional selalu membawa misi yang ingin disampaikan kepada penonton. Misi atau pesan itu dapat bersifat sosial, politik, moral, dan sebagainya. Sebenarnya dalam setiap pertunjukan seni tradisional ada beberapa nilai tertentu yang dikandungnya. Seni pertunjukan tradisional secara umum mempunyai empat fungsi yang paling dominan adalah fungsi ritual dan fungsi pendidikan sebagai media tuntunan. Kehadiran kelompok-kelompok seni Dolalak sebagai sebuah bentuk seni pertunjukan tradisional di wilayah Purworejo dan sekitarnya telah menghasilkan dampak ke masyarakat pemiliknya. Beberapa fungsi atas kehadiran seni Dolalak bagi masyarakat Purworejo dan sekitarnya sebagai berikut:

1. sebagai alat pendukung/sarana upacara adat dan ritual bagi masyarakat setempat, hal ini terbukti bahwa pementasan seni Dolalak sering pada acara-acara/kegiatan bersih desa 'ritual membersihkan desa dari segala sesuatu yang mengganggu kehidupan masyarakatnya'. Selain itu, pada acara ruwatan, hajatan khitanan, upacara perkawinan, kegiatan yang bersifat religi seperti peringatan Isra' Mi' raj dan Maulid Nabi Muhammad S.A.W. dan lain-lain.

a. sebagai sarana hiburan, seni Dolalak ini sering juga dipentaskan dalam acara-acara seremonial 'upacara formal' kedaerahan dalam rangka kegiatan peresmian atau pembukaan acara tertentu dari tingkat kabupaten sampai dengan tingkat RT/RW. Selain itu pada setiap peringatan 17 Agustusan dan hari-hari penting lainnya, seni Dolalak selalu dipentaskan sebagai pengisi acara. Demikian juga ketika ada acara penyambutan tamu dan kegiatan perayaan-perayaan lain dalam suasana gembira, seni Dolalak selalu ditampilkan sebagai bentuk acara hiburan.

b. sebagai media komunikasi, pendidikan, dan kritik sosial dalam masyarakat, karena dengan adanya pementasan seni tradisional Dolalak ini bisa menimbulkan sebuah atau lebih interaksi sosial dalam masyarakat pendukungnya. Bahkan peristiwa seni ini juga dapat menumbuhkan jalinan hubungan 
yang harmonis antara pemimpin dengan rakyat, sesama, dan lainlain.

c. sebagai sarana pewarisan budaya dan pengucapan sejarah, seiiring dengan kegiatan pertunjukan seni Dolalak juga diselipi pesan-pesan untuk tetap menjaga adat istiadat dan budaya setempat, bahkan cerita sejarah nenek moyang yang mereka yakini ada hubungannya dengan keberadaan wilayah dan atau tokohtokoh cikal bakal dari masyarakat setempat.

d. sebagai sarana pelestarian etos kerja gotong royong, sebagaimana kegiatan-kegiatan seni budaya tradisional yang lain, keberadaan kelompok-kelompok seni Dolalak dalam masyarakat pemiliknya menumbuhkan rasa sosial, persatuan, dan sifat kegotongroyongan di antara mereka. Etos kegotong-royongan itu misalnya bisa ditunjukan dalam kegiatan pementasan yang dapat melibatkan 30--35an orang penyaji, jika sang penanggap tidak menyadari hal itu maka dia tidak akan mengundang sebuah kelompok seni Dolalak karena dia harus menyediakan makan, minum, tempat, dan fasilitas lain untuk kegiatan pementasan itu.

Kesenian rakyat Dolalak ini memang menarik, bukan hanya karena kostumnya yang unik atau gerakannya yang anehaneh ataupun irama musik pengiringnya yang mengajak untuk ikut bergerak-gerak, tetapi saat ini kekuatan dan daya tarik seni tradisional inijustru terletak pada keberadaan penarinya yang biasanya gadis-gadis manis usia belasan tahun. Unsur-unsur gerak tarian dolalak memang terasa sebagai gerak tari keprajuritan. Jika kita amati dengan jeli, di situ ada jurus-jurus pencak silat atau bela diri. Ada gerak pukulan yang tajam mengarah titik-titik lemah lawan, tetapi ada juga tangkisan-tangkisan yang menghentak untuk menghindari serangan lawan. Keseluruhan gerak itu tak nampak patah-patah, seperti layaknya sebuah gerakan kanuragan karena terbalut oleh gerakan-gerakan naluri seorang wanita, sehingga menjadi gerak tari yang gemulai dan enak ditonton.

Kostum yang mereka kenakan pun jelas menunjukkan ciri-ciri tari keprajuritan. Atasan berupa baju seorang prajurit, lengkap dengan selempang dan rumbai-rumbai di kedua pundaknya. Sebentuk topi bertengger di kepala, berwarna sama dengan baju tadi. Sayang, jika kostum tersebut dimaksudkan sebagai seorang prajurit, maka rasanya jadi kurang pas dengan legendanya. Sebab, justru jadi lebih mirip dengan kostum prajurit kompeni Belanda. Tidak apa-apa, toh namanya juga kostum tarian. Yang menarik adalah bawahannya. Celana pendek sedikit jauh di atas lutut, sehingga -maaf- paha-paha putih para penari nampak demikian sensual. Ternyata putihnya paha dan betis penari bukan lantaran bedak pemutih, tetapi karena sepasang stocking yang mereka kenakan. Kesenian dolalak umumnya diiringi sebuah kendang, rebana, saron, dan kadangkadang seruling. Sekarang ini malah sudah dilengkapi pula dengan drum, bahkan kalau ada sebuah organ/keyboard.

Seiring perkembangan zaman dan teknologi, tarian Dolalak sekarang sudah diringi dengan musik modern, yaitu keyboard. Lagu-lagu yang dimainkan pun bervariasi dan beragam. Saat ini kebanyakan penari Dolalak hanya dilakukan oleh para wanita, berseragam hitam dengan aksesoris yang gemerlapan juga ada aksesoris yang khas yaitu kacamata hitam. Sebagaian dari para penari Dolalak dapat mengalami trance, yaitu suatu kondisi mereka tidak sadar karena sudah begitu larut dalam tarian dan musik

Peranan perempuan dalam bentuk kegiatan kesenian tradisional sudah terjadi cukup lama, peran mereka juga cukup kuat dan penting dalam mempertahankan sebuah tradisi budaya, khususnya seni. Tanpa kehadiran mereka, rasanya bagai sayur kurang garam atau hambar. Di samping 
itu, kehadiran perempuan sebagai tokoh dalam pementasan seni pertunjukan dapat menguatkan mitos bahwa perempuan bukan sebagai obyek melainkan dapat juga sebagai subyek yang harus disejajarkan dengan peran kaum pria dalam bidang seni ini.

Kesenian merupakan bagian kehidupan manusia. Setiap bangsa di dunia ini pasti mempunyai kekhasan dalam berkesenian dengan agama kehidupan manusia akan menjadi terarah, dengan ilmu pengetahuan kehidupan manusia akan lebih mudah, dan dengan kesenian kehidupan manusia akan lebih indah. Membicarakan seni sama hanya membicarakan manusia karena seni itu merupakan hasil tindakan manusia (Simatupang, 2006: 1).

Tarian Dolalak saat inisudah berkembang pesat bahkan sudah menjadi brand image Kabupaten Purworejo. Dolalak semakin populer di kalangan generasi muda. Hal ini tidak luput dari peran Pemerintah Daerah Purworejo yang terus mengembangkan dan melestarikan kesenian asli daerah Purworejo ini. Bahkan di setiap event-event tingkat nasional kesenian Dolalak selalu tampil sebagai suatu kesenian yang unik. Di setiap lomba-lomba kesenian tingkat nasional kesenian Dolalak selalu menjuarai. Hal inilah yang selalu mendorong seni Dolalak selalu ditampilkan dalam Dirgahayu Kemerdekaan Republik Indonesia, Jambore Pramuka dari tingkat daerah sampai Nasional, pertunjukkan budaya antar-daerah, bahkan sudah melanglang ke beberapa negara di Asia dan Eropa. Oleh karena itu, Dolalak perlu dipatenkan sebagai kesenian asli Indonesia pada umumnya dan menjadi kesenian asli daerah Kabupaten Purworejo pada khususnya. Hal ini bertujuan agar Dolalak tidak diklaim sebagai milik perseorangan, daerah lain, atau bahkan bangsa lain

\section{SIMPULAN}

Awal kemunculan tari Dolalak berkaitan dengan penjajahan Belanda di Daerah Purworejo karena Purworejo dipakai pusat pertahanan serdadu Belanda sehingga didirikan tangsi untuk asrama militer Belanda. Mereka yang tinggal di tangsi bukan hanya orang Belanda saja, tetapi juga pemuda-pemuda pribumi dari berbagai daerah. Mereka diwajibkan dan dilatih kemiliteran menjadi prajurit Belanda. Kehidupan di dalam asrama yang penuh dengan kedisiplinan dan kekerasan itu membuat mereka bosan sehingga perlu hiburan. Pada waktu istirahat mereka menghibur dirinya dengan berbagai cara, di antaranya menari, menyanyi, pencak silat, kadang ada yang menirukan gerak dansa di dalam tangsi, kemudian di tirukan oleh masyarakat Purworejo dengan nada do-la-la yang orang Jawa menyebutnya "dolalak".

Kesenian tari Dolalak pada awalnya di tarikan oleh penari laki-laki, tetapi dalam perkembangnya, tari Dolalak ditarikan oleh penari perempuan. Hampir disetiap grup kesenian tari Dolalak di Purworejo, semua penarinya perempuan, salah satu kelompok yang masih mempertahankan penari lakilaki adalah di Desa Kaliharjo, Kaligesing juga memiliki kelompok penari-penari perempuan sebagai penari utamanya.

Kesenian tari Dolalak mempunyai keunikan bahwa tari Dolalak ditemukan beberapa perbedan karakter pembawanya sesuai dengan kelompok usia dan perkembangan zaman. Perkembanganya iringan musik diiringi dengan menggunakan instrumen jedur, terbang, kencer, dan kendang. Syair yang digunakan dalam tari Dolalak berisi tuntunan shalat, mengaji, kerja bakti, dan lain-lain.

Kelompok kesenian Dolalak di Desa Kaliharjo Kaligesing ini diawali oleh tokohtokoh seperti CokroSumarto, SastroSumanto, Suprapto, Amat Yusro, dan Martoguno. Ketertarikan mereka terhadap kesenian ini berawal dari menyaksikan pentas kesenian tari Dolalak di wilayah Trirejo, Loano, yang kemudian mendirikan kelompok kesenian Dolalak di Desa Kaliharjo pada tahun 1936. Tokoh utamanya adalah Cokro Sumarto sebagai pendiri kesenian tari Dolalak di Desa Kaliharjo. Cokro Sumarto sebagai tokoh agama yang taat dan di hormati. Cokro Sumarto mempunyai peran yang penting 
dalam pemahaman Islam karena di samping sebagai tokoh agama juga seniman. Cokro Sumarto semakin mempunyai pengaruh dalam hal penyebaran agama Islam setelah mendirikan kelompok kesenian tari Dolalak.

Mempelajari sejarah perkembangan agama Islam tidak dapat dilepaskan begitu saja dari sejarah perkembangan kesenian tradisional, khususnya tari Dolalak. Penelitian dan pendokumentasian seni tradisional khususnya seni Dolalak dapat memberikan sumbangan dalam rangka melestarikan nilai-nilai budaya bangsa Indonesia dan budaya daerah pada khususnya, Menambah khasanah ilmu pengetahuan mengenai sejarah budaya kesenian tari tingkat lokal sebagai karya yang menarik, berbobot serta tidak membosankan sehingga diharapkan dapat memperkaya khazanah intelektual khususnya di bidang sejarah seni.

Pembahasan mengenai seni pertunjukan tradisional Dolalak di Wilayah Purworejo dan sekitarnya, tidak dapat dipisahkan dari beberapa permasalahan yang masih perlu untuk dikaji secara mendalam. Permasalahan itu di antaranya adalah hubungan sejarah antara seni Dolalak dengan latar belakang masyarakat pendukungnya. Sebagai bentuk kegiatan seni, Dolalak juga memiliki hubungan yang kuat dengan keberadaan tradisi masyarakat sekitar pendukungnya, terutama dihubungkan dengan cerita rakyat atau legenda yang ada di lingkungan masyarakat setempat.

Keberadaan seni Dolalak juga dapat dikaji dalam hubungannya dengan perubahan penari utamanya dari kaum lakilaki ke kaum perempuan, bahkan kehadiran penari perempuan inilah yang menjadikan eksistensi seni tradisional ini semakin kuat di masyarakat pendukungnya. Dalam kaiatan permasalahan ini, penari perempuan dangan segala atributnya telah menjadi ciri khas, bahkan telah menjadi identitas budaya bagi masyarakat pendukungnya. Kiprah dan peran kaum perempuan dalam pementasan seni Dolalak di lingkungan wilayah Purworejo dan sekitarnya telah menghasilkan fungsi dan manfaat yang tidak kecil bagi masyarakat pendukungnya.

Permasalahan lain yang juga menarik untuk bisa dikaji lebih dalam adalah mencari benang merah dan hubungan antara keberadaan sebuah seni pertunjukan dengan bidang ilmu lain, seperti sastra dan bahasa. Dalam hubungannya dengan seni Dolalak, kajian ini dapat dimulai dengan melakukan penelitian dan analisis terhadap syair-syair tembang-tembang yang disajikan dalam pementasannya, juga penelitian terhadap peristiwa trance/mendem 'kesurupan roh' yang biasanya dialami oleh penari-penari Dolalak. Peristiwa ini dalam dunia sastra lama, sudah banyak diungkap dalam naskahnaskahnya, baik dalam sastra Jawa masa lalu maupun sastra Bali.

Pembahasan permasalahan-permasalahan tersebut secara mendalam masih perlu dilakukan agar kehadiran seni Dolalak sebagai sebuah bentuk seni pertunjukan tradisional benar-benar dapat diungkapkan, sekaligus masayarakat lebih dapat menghargai terhadap kehadirannya.

\section{DAFTAR PUSTAKA}

Ahimsa-Putra, Heddy Shri. 2000. "Seni dalam Beberapa Perspeftif: Sebuah Pengantar" dalam Ketika Orang Jawa Nyeni. Yogyakarta: Galang Press.

Alasuutari, Pertti. 1996. Researching Culture: Qualitative Method and Cultural Studies. London: Sage Publications

Bandem, I Made dan Sal Murgiyanto. 1996. Teater Daerah Indonesia. Yogyakarta: Kanisius.

Brandon, James R. 1967. Theatre in Southeast Asia. Cambridge, Massachusetts: Harvard University Press.

Budianto, Melani. 1998. Sastra dan Ideologi Gender. Jakarta: Gramedia

Caturwati, Endang, 2003. Lokalitas, Gender, dan Seni Pertunjukan di Jawa Barat. Yogyakarta: Aksara Indonesia.

Cohen, Matthew Isaac, dkk. , “Seni Pertunjukan Indonesia Melintas Batas", terjemahan Noor Cholis 
dalam Indonesia and the Malay World Volume 35, Issue 101 Maret 2007.

Endraswara, Suwardi. 2003. Metodologi Penelitian Kebudayaan. Yogyakarta: Gadjah Mada University Press.

Geertz, Clifford. 1992. Tafsir Kebudayaan terjemahan Budi Susanto S.J. Yogyakarta: Kanisius, 1992.

Haryono, Timbul. 2009. "Peran Masyarakat Intelektual dalam Penyelematan dan Pelestarian Warisan Budaya Lokal" dalam Pidato Ilmiah dalam rangka Dies Fakultas Ilmu Budaya UGM ke63 tanggal 3 Maret 2009. Yogyakarta.

Holt, Claire. 2000. Melacak Jejak Perkembangan Seni di Indonesia, pengantar dan terjemahan Prof. Dr. RM. Soedarsono. Bandung: Masyarakat Seni Pertunjukan Indonesia.

Imansyah Hadad, M. 2006. Wisata Ziarah Kabupaten Purworejo. Purworejo: Pemerintah Kabupaten Purworejo.

Kartodirdjo, Sartono. 1988. Pembangunan Pedesaan di Indonesia. Yogyakarta: Liberty.

Kusmiyati, A.M. Hermien. April 2006. "Seni dan Keperkasaan Perempuan" makalah seminar memperingati hari Kartini bulan April tahun 2006 di Kampus Institut Seni Indonesia (ISI) Surakarta.

Laksono, PM. 1985. Kebudayaan Jawa. Jakarta: PT Gramedia Pustaka.

Margana. 2010. Kraton Surakarta dan Yogyakarta 1769-1874. Yogyakarta: Pustaka Pelajar.

Radix Penadi, 2005. Bagelen Kawasan yang Dikerdilkan. Purworejo: Lembaga Studi dan Pengembangan Sosial Budaya.

Sedyawati, Edi. 1981. Pertumbuhan Seni Pertunjukan. Jakarta: Sinar Harapan

Simatupang, G.R. Lono Lastoro. 2006. "Jagad Seni: Refleksi Kemanusiaan"
Makalah Workshop Festifal

Seni Tradisi Lisan. Yogyakarta: Departemen Kebudayaan dan Pariwisata, Balai Kajian Sejarah dan Nilai Tradisional.

Soedarsono, R.M. 1985. Peranan Seni Budaya

Dalam Sejarah Kehidupan Manusia; Kontinuitas dan Perubahannya. Yogyakarta: Pidato Pengukuhan Jabatan Guru Besar pada Fakultas Sastra Universitas Gadjah Mada tanggal 9 Oktober 1985. . 1999. Metodologi Penelitian Seni Pertunjukan dan Seni Rupa. Bandung: MSPI (Masyarakat Seni Pertunjukan Indonesia)

Indonesia di Era Globalisasi. Yogyakarta: Gadjah Mada University Press.

Spradley, James P.m 1997. Metode Etnografi diterjemahkan oleh Misbah Zulfa Elizabeth. Yogyakarta: PT. Tiara Wacana Yogyakarta.

Van Der Meulen, W.J., 1988. Indonesia Diambang Sejarah. Yogyakarta: Kanisius.

\section{Nara Sumber:}

1. R. Tjipto Siswojo, 60 tahun, Desa Kaliharjo Kecamatan Kaligesing Kabupaten Purworejo Jawa Tengah, pimpinan grup seni Dolalak "Budi Santosa";

2. Tijab, 55 tahun, Desa Giri Tengah Kecamatan Borobudur Kabupaten Magelang Jawa Tengah, pimpinan grup seni Dolalak "Arum Lestari Budaya";

3. Soekoso DM; Tokoh Masyarakat Purworejo.

4. Karyadi, 70 tahun, Desa Mlaran Kecamatan Gebang dan dirintis oleh Kabupaten Purworejo Jawa Tengah, pimpinan grup seni Dolalak "Sri Dadi" dan "Sri Arum". 